\title{
Acquired Urinary Tract Obstruction
}

National Cancer Institute

\section{Source}

National Cancer Institute. Acquired Urinary Tract Obstruction. NCI Thesaurus. Code C123241.

A urinary tract obstruction, the cause of which is not present at birth. 